\title{
Enhanced design of precast concrete columns by optimal axial steels
}

\author{
C. Shim, S. Park, S. Lee \& C. Koem \\ Department of Civil Engineering, Chung-Ang University, Korea
}

\begin{abstract}
Prestressed precast concrete columns are recently considered as excellent design options due to their self-centering capability for seismic actions. Axial prestressing is designed to control cracking at the precast joints by service loads. In this paper, a combination of continuous reinforcing bars and prestressing tendons was suggested to enhance seismic performance as well as economy of precast piers. Cyclic tests were conducted to verify the suggested concept. By preventing buckling and fracture of the reinforcing bars in the plastic hinge region, the test specimens showed remarkable ductility without reduction of their flexural strength. Appropriate magnitude of initial prestressing force was also proposed to prevent fracture of tendons by large lateral deformation of columns in strong earthquakes.

Keywords: precast concrete column, axial steel, cyclic test, ductility, prestressing force.
\end{abstract}

\section{Introduction}

The prefabrication of bridge structures to minimize on-site construction operations has shown increasing demand due to their improved safety and economic advantages. A shortened construction time can be achieved because precast construction system shifts the location of time consuming cast-in-place tasks to off-site factories resulting in parallel construction process. Precast concrete elements using high performance materials provide a higher quality and more attractive finish including decorative design.

Bridge piers in seismic areas should be designed to have plastic hinges for energy dissipation. Post-tensioned precast columns showed a joint opening because longitudinal mild steel reinforcements are discontinuous at the column 
joints [1]. Without the plastic design of bridge columns for seismic actions, the dimensions of the columns are practically non-economical. However, the selfcentering capability of precast prestressed concrete columns can minimize residual displacement and damage for seismic actions resulting in superior seismic performance [2]. Unbonded posttensioning was adopted for recentering the structural system [3] and the prestressing level of the tendons influenced the seismic behaviour of precast segmental columns [4].

Prestressing threaded bars were utilized to introduce compression to the segment joints and to enhance ductility due to bonded characteristics [5]. Prefabricated composite columns with embedded circular tubes showed enhanced ultimate strength and energy absorption capacity [6]. Precast pier cap can be divided into segments to reduce cost for lifting equipment [7]. Considering the design conditions of a bridge, appropriate design parameters should be determined to obtain required seismic performance.

In this paper, a new attempt of precast bridge pier was proposed. Different combination of axial steels was considered such as posttensioned tendons and continuous reinforcing steels. As shown in Figure 1, a combination of bonded

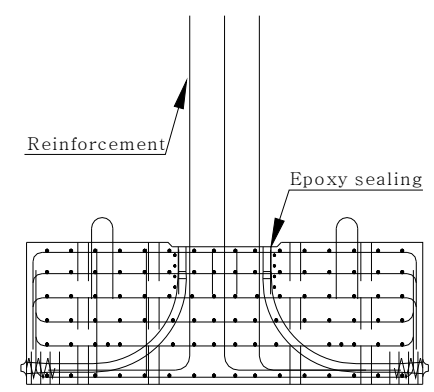

(a) Continuous reinforcing bars

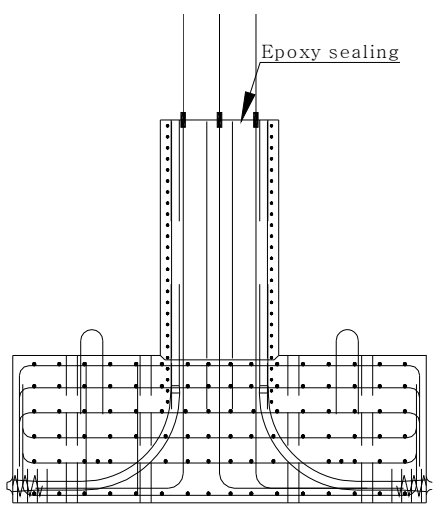

(c) Coupling of reinforcing bars

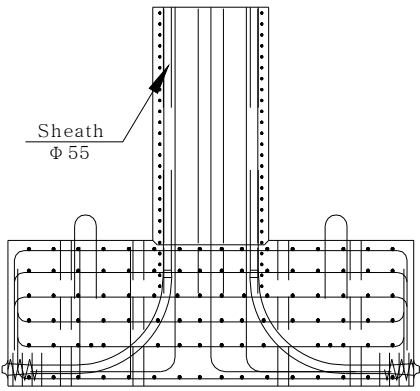

(b) segment installation

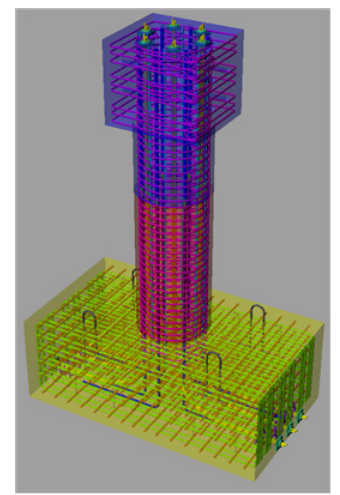

(d) 3D model of the precast pier

Figure 1: Prefabricated bridge pier details and 3D model. 
tendons and continuous reinforcements crossing the joints was adopted to minimize the required prestressing tendons. $3 \mathrm{D}$ digital models $[8,9]$ were utilized for design and fabrication. Joint shapes and duct couplers were proposed to enhance structural performance of the pier.

\section{Experiments on precast columns}

\subsection{Test specimens}

Five precast pier specimens with a circular solid section of $800 \mathrm{~mm}$ diameter were fabricated and tested under cyclic loadings. The main parameters of the specimens were the axial steel ratio, the magnitude of effective prestress, continuity of axial steels, and transverse reinforcement. Axial load including prestress was applied to the columns from $16 \%$ to $31 \%$ of the compressive strength of the columns. Effective prestress of the tendons had a range from $43 \%$ to $77 \%$ of the yield strength of the tendon.

For bonded posttensioning systems of precast columns, the corrugated steel ducts embedded in concrete were grouted with cementitious materials after the prestressing tendons were stressed so as to generate a bond between the tendons and surrounding concrete, which can increase the lateral strength of the columns. Magnitude of the effective prestress is determined to control cracking of the segments joints under service loads. Provided continuous reinforcing bars crossing the joints, allowable tensile stress of concrete can be utilized. Except for one specimen, there are continuous deformed reinforcing bars of $32 \mathrm{~mm}$ crossing the joints. Figure 2 presents one of the details of a test specimen.

The segmental assembly bridge pier specimen was divided into 3 parts. Without match-casting method in fabrication process, the segments were fabricated using 3D engineering. Steel formworks were designed using BIM (Building Information Modeling) tools, and metal forming machine tools were utilized for accurate surface match. A 3D printer was also utilized to fabricate duct couplers at the joints.

Material properties of concrete, reinforcing bars and prestressing steel were obtained. Average compressive strength of concrete for five specimens was $35.6 \mathrm{~N} / \mathrm{mm}^{2}$. The yield strengths of the reinforcing bar and prestressing tendons were $400 \mathrm{~N} / \mathrm{mm}^{2}$ and $1640 \mathrm{~N} / \mathrm{mm}^{2}$, respectively. Epoxy had bond strength greater than tensile strength of concrete.

Quasi-static tests were conducted to evaluate seismic response of the precast columns. Figure 3 shows the test setup. Repeated lateral forces were simultaneously applied to the column by a hydraulic actuator mounted on the reaction wall. Axial force was applied by two hydraulic jacks. The displacementcontrolled test was performed from $0.25 \%$ to $8.0 \%$ of the drift ratio. 
270 Earthquake Resistant Engineering Structures X
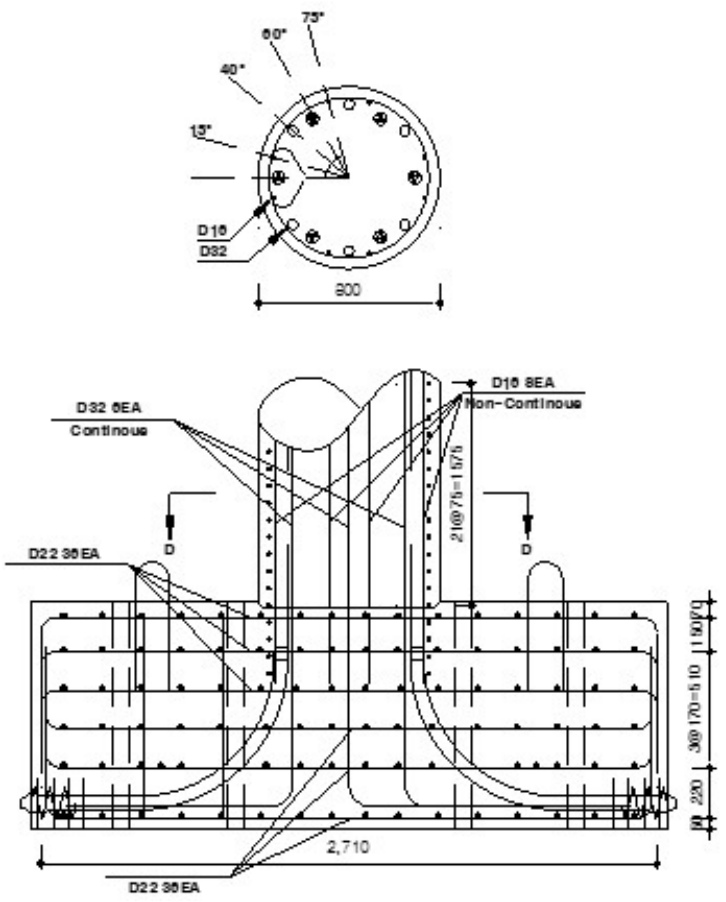

Figure 2: Test specimen details.

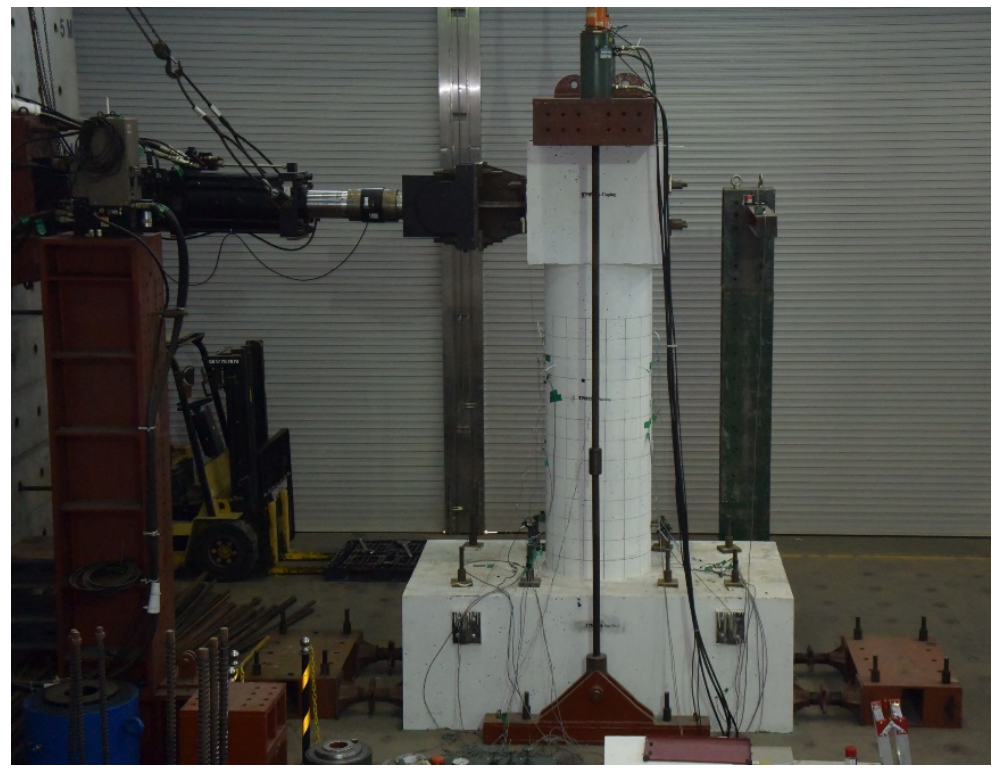

Figure 3: Test setup. 


\section{Test results}

Common failure modes of reinforced concrete columns under cyclic loadings are the buckling and fracture of axial reinforcing bars after spalling of the cover concrete. Precast concrete columns with central unbonded prestressing tendons showed that the joint opening of precast segments tends to prevent plastic hinging from happening for the column with reinforcing bars discontinuous at the joints [3].

From measured displacement of the specimen, envelope curves were derived (as shown in Figure 4). Three specimens of PSRC8-L were obtained from the previous tests [7] with the same diameter of the column and aspect ratio. The ultimate strength of the precast columns in these experiments showed from $467 \mathrm{kN}$ to $659 \mathrm{kN}$, which was a significant increase. The continuous reinforcing bars contributed significantly to the ductile failure mode and ultimate strength resulting in an increase of deformation capacity.

Up to a maximum drift ratio of $8.0 \%$, the precast columns did not show a decrease of the maximum strength. Reinforcing bars were located inside of the extreme fibre and prestressing steels were located at the extreme fibre. This arrangement prevented buckling and fracture of the bars up to a large drift ratio. The displacement ductility of the precast columns was greater than 3.5 (minimum) or 5.6 (maximum) based on the observed deformation. Because of the stroke limit, the lateral displacement could not be increased. Therefore, it was expected to have a significant increase of ductility compared with the previous experiments [7].

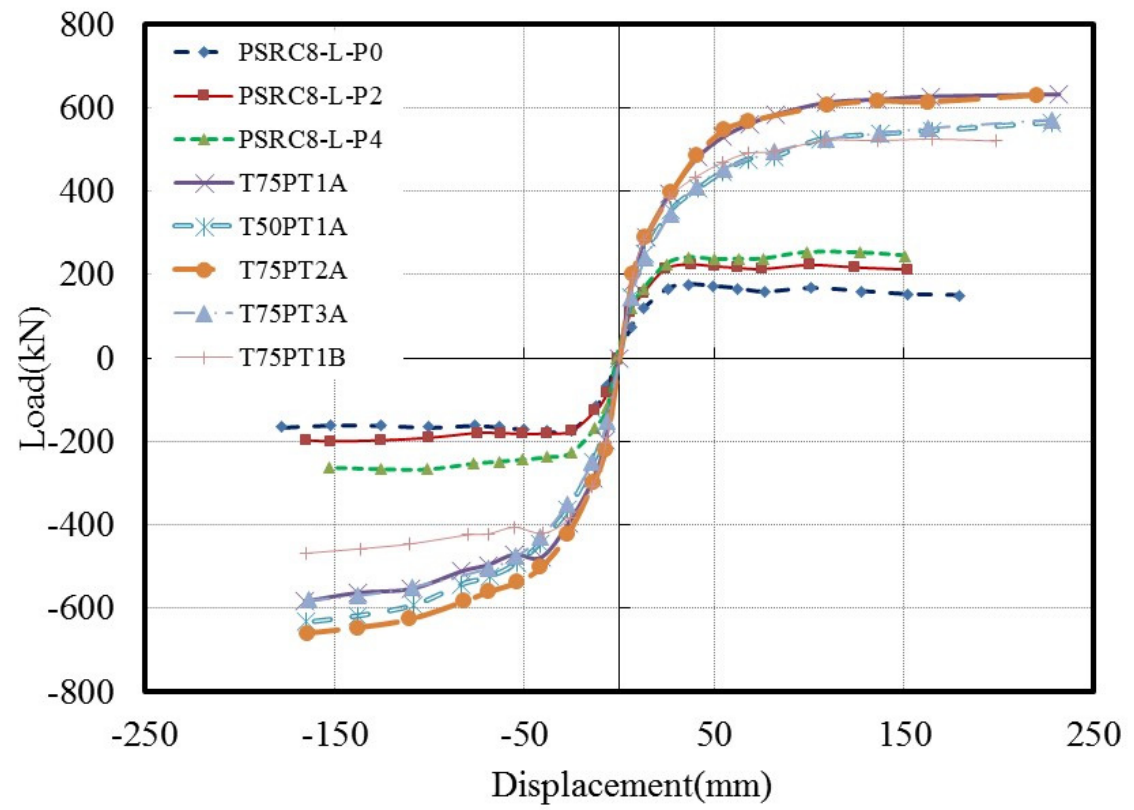

Figure 4: Envelope curves of precast columns. 


\section{Conclusions}

From the observation of previous experience on prestressed precast concrete columns, enhanced design concepts were proposed to increase strength and ductility of the precast bridge piers. Cyclic tests were conducted to evaluate seismic performance of the proposed precast columns.

A combination of bonded prestressing tendons and mild reinforcement steel crossing the segment joints showed significant increase of ultimate strength and ductile failure modes. The arrangement of the axial steels for the prevention of premature buckling or fracture by lateral displacement enhanced seismic performance remarkably.

\section{Acknowledgements}

This research was supported by a grant (13SCIPA01) from Smart Civil Infrastructure Research Program funded by Ministry of Land, Infrastructure and Transport (MOLIT) of the Korean government and the Korea Agency for Infrastructure Technology Advancement (KAIA).

\section{References}

[1] Hewes, J. T., and Priestley, M. J. N., Seismic design and performance of precast concrete segmental bridge columns. Rep. No.SSRP-2001/25, Univ. of California, San Diego, 2002.

[2] Dowood, H. ElGawady, M., and Hewes, J., Behavior of Segmental Precast Posttensioned Bridge Piers under Lateral Loads, Journal of Bridge Engineering, 17(5), pp. 735-746. 2012.

[3] Ou, Y., Chiewanichakorn, M., Aref, A., \& Lee, G., Seismic performance of segmental precast unbonded posttensioned concrete bridge columns. Journal of Structural Engineering, 133(11), pp. 1636-1647, 2007.

[4] Nikbakht, Ehsan, Rashid, Khalim, Hejazi, Farzad, \& Osman, Siti A., A numerical study on seismic response of self-centring precast segmental columns at different post-tensioning forces. Latin American Journal of Solids and Structures, 11(5), pp. 864-883, 2014.

[5] Shim CS, Chung CS, Kim HH., Experimental evaluation of seismic performance of precast segmental bridge piers with a circular solid section, Engineering Structures, 30(12), pp. 3782-3792, 2008.

[6] Shim CS, Kim DW, Kong D. Structural performance of precast segmental composite pier cap, Proc. of 18th Congress of International Association for Bridge and Structural Engineering, pp. 1988-1993, 2012.

[7] Shim CS, Chung YS and Yoon JY., Cyclic Behavior of Prefabricated Circular Composite Columns with Low Steel Ratio, Engineering Structures, 33(9), pp. 2525-2534, 2011. 
[8] Lee KM, Lee YB, Shim CS, Park KL., Bridge information models for construction of a concrete box-girder bridge, Structure and Infrastructure Engineering, 8(7), pp. 687-703, 2012.

[9] Shim CS, Lee KM, Kang LS, Hwang J and Kim YH. Three-Dimensional Information Model-based Bridge Engineering in Korea, Structural Engineering International, 22(1), pp. 8-13, 2012. 